\title{
$\mathrm{GA}$ 를 이용한 휴머노이드 로봇의 넘어짐 자세 생성
}

\section{Generation of Falling Motion for Humanoid Robot Using GA}

\author{
안광철 * 조영 완 ${ }^{* *}$ - 서기성 ${ }^{*+}$ \\ Kwangchul $\mathrm{An}^{*} \cdot$ Young-Wan $\mathrm{Cho}^{*} \cdot$ Kisung Seo ${ }^{*+}$ \\ ^서경대학교 전자공학과 \\ **서경대학교 컴퓨터공학과
}

요 약

본 논문은 휴머노이드 로봇이 넘어질 경우, 충격에 의한 손상을 최소화하기 위한 자세의 자동 생성 방법을 제안한다. 유 전알고리즘 $(\mathrm{GA})$ 를 사용하여 로봇이 전방 또는 후방으로 넘어질때 충격량둥을 최소화 할수 있는 관절각들의 퀘적을 구하였 다. 또한, 다양한 적합도 함수를 정의하여 서로 다른 넘어짐 자세를 생성할수 있도록 하였다. 제안된 기법의 검증을 위하여 Sony QRIO 로봇에 대해서 ODE 기반 물리적 특성의 시뮬레이션이 가능한 Webots를 이용하여 실험을 수행하였다.

키워드 : 넘어짐 자세 생성, 휴머노이드 로봇, 유전 알고리즘, Sony QRIO, Webots

\begin{abstract}
This paper introduced an automatic generation method of falling motions for humanoid robots to minimize a damage. The proposed approach used a GA based optimization technique to find a set of joint trajectories which minimize a damage of the falling over and down. A couple of fitness functions are provided to generate various falling motions. To verify the proposed method, experiments for falling motions were executed for Sony QRIO robot in Webots simulation environments.
\end{abstract}

Key Words : Falling Motion Generation, Humanoid Robot, Genetic Algorithm, Sony QRIO, Webots

\section{1. 서 론}

다리로 걷는 보행로봇은 바퀴 로봇보다 장애지형이나 평 평하지 않은 지형에서도 이동이 가능하고, 특히 휴머노이드 로봇의 경우, 인간과 가장 근접한 외형과 동작 모양새를 갖 추고 있어 여러 분야에서 널리 사용 될 전망이다. 휴머노이 드 로봇에 대한 연구는 주로 보행에 초점이 맞추어져 있고 [1-4], 일부 전신 동작에 대한 제어등이 시도되고 있다[5].

그러나, 휴머노이드 로봇은 지면을 지지하고 있는 면적이 좁고 무게중심 또한 높게 위치하여 전복 상황 시 충격으로 로봇이 손상을 입을 확률이 높다. 따라서 안정적인 보행도 중요하지만 전복 될 경우에 손상 및 충격을 최소화하기 위한 넘어짐 자세의 제어가 요구된다[6,7]. 휴머노이드 로봇의 넘 어짐 자세 생성은 로봇에 가해지는 충격랑을 최소화 할 수 있도록 시간의 변화에 따른 관절 움직임의 최적 조합을 설계 해야 하는 어려운 문제이다.

\footnotetext{
접수일자 : 2007년 11월 14일

완료일자 : 2007년 12월 1일

감사의 글 : 이 논문은 2006년 정부재원(교육인적자원

부 학술연구조성사업비)으로 한국학술진흥재단의 지원

을 받아 연구되었음(KRF-2006-311-D00146)

+ +교신 저자 : 서기성
}

지금까지 넘어짐 자세 연구는 사람의 동작을 모방하여 반 복적인 시뮬레이션을 통해 수작업으로 구해지는 방식[6] 또 는 움직임을 수학적으로 해석한 제어방법[7] 등이 있다.

기존 연구의 문제점은 반복적인 시뮬레이션을 통해 얻어 진 경우[6], 로봇의 형태나 모델이 바필시, 새로 시간이 많이 소요되는 반복적인 작업을 다시 수행해야 하며, 구한 결과가 최적의 자세인지를 판별하기가 어럽다. 수학적 제어에 의한 접근법[7] 또한 넘어지는 동작의 주요 관절들의 관계를 정의 하고, 각 관절의 모맨트를 분석하여 관절각의 변화 속도에 제 동을 가하는 방법을 사용함으로써, 전체 관절 움직임 조합에 의해 생성될 수 있는 충격량 최소화 자세와는 거리가 있다.

본 연구에서는 GA(Genetic Algorithm)[8]를 이용하여 전 방 및 후방 넘어짐 자세에 대한 자동 생성 기법을 제안한다. 다양한 모델에 대해서 적용이 가능하며, $\mathrm{GA}$ 의 성능에 따라 최적에 가까운 값을 탐색할 수 있는 장점이 존재한다. 즉, 관 절공간에서의 관절각의 조합을 $\mathrm{GA}$ 로 탐색하여 충격량을 최 소화하는 넘어짐 자세 생성 방법을 구현한다. 제안된 기법의 검증을 위하여 Sony QRIO 로봇에 대해서 ODE 가반의 물 리적 특성을 포함하고 정교한 시뮬레이션이 가능한 Webots [9]을 이용하여 실험을 수행하였다. 


\section{2. 휴머노이드 로봇의 넘어짐 자세}

\section{1 휴머노이드 로봇 모델}

넘어짐 자세 생성을 위한 휴머노이드 로봇 모델은 Sony QRIO(Quest for Curiosity)를 사용하였다(그림1). QRIO는 크기가 $260(\mathrm{~W}) \times 190(\mathrm{D}) \times 580(\mathrm{H}) \mathrm{mm}$, 중량은 약 $6.5 \mathrm{~kg}$ 로서 전부 38 개의 관절로 구성된다. 보행 속도는 비평지면에서 최 고 약 $0.36 \mathrm{~km} / \mathrm{h}$, 수평, 평지면에서 최고 약 $1.2 \mathrm{~km} / \mathrm{h}$ 로 보 행할 수 있다[6].
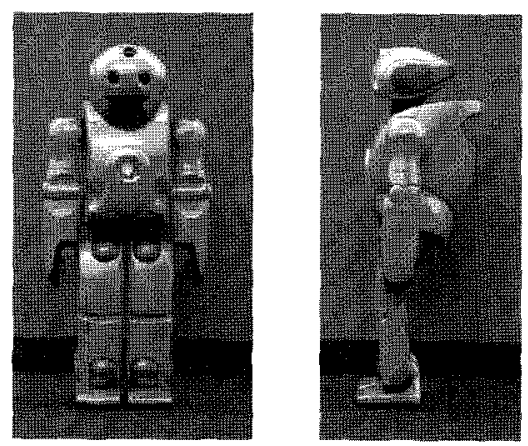

그림 1. Sony $\mathrm{QRIO}$ 로봇

Fig. 1. Sony QRIO robot

\section{2 넘어짐 자세의 관절 좌표계 표현}

휴머노이드 로봇의 넘어짐 자세는 초기의 서 있는 자세에 서 최종 넘어져 있는 자세까지 시간에 따른 각 관절각의 조 합으로 구성된 집합들로 나타내어질 수 있다. 각 관절값들은 상한 과 하한의 한계 범위 내에서 임의의 실수값을 가지며, 하나의 임의 시점에서 구성될 수 있는 관절각들의 조합은 큰 탐색 공간을 구성한다.

더욱이 전체 넘어짐 자세는 한 시점에서의 관절값 집합이 여러 구간점에서 $\left(t_{1}, t_{2}, \ldots, t_{n}\right)$ 전체 집합으로 확장되어야 하 므로, 전체 해 공간은 매우 방대해진다(그림 2).

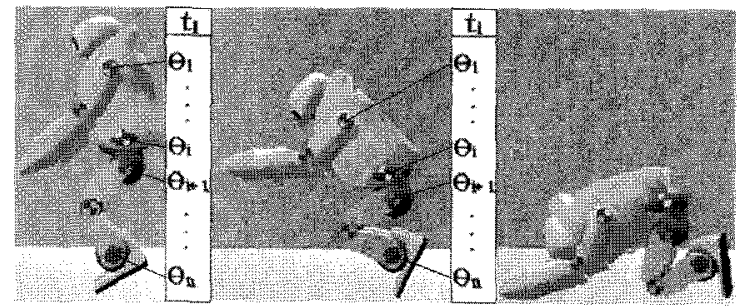

그림 2. 자세 생성을 위한 관절각 조합

Fig. 2. Joints set for robot motions

\section{3. $\mathrm{GA}$ 기반 넘어짐 자세 자동 생성}

$\mathrm{GA}$ 를 이용하여 관절 좌포계 상에서의 관절각 값을 시점 에 따라 변화시켜 안정적인 넘어짐 자세를 생성하는 방법으 로 지면과 접촉되는 부위에 압력 센서를 부착시켜 그 값이 최소가 되는 동작을 얻음으로써 충격량을 최소로 하는 동작 을 생성할 수 있다. 이러한 방법은 로봇의 모델 및 환경이 변 하여도 최소한의 수정만으로 적용이 가능하며 최적의 동작을 근사할 수 있기 때문에 큰 장점을 갖는다.

\subsection{GA 염색체 (chromosome) 구성}

휴머노이드 로봇이 전방으로 넘어지는 경우를 가정하고, 전방향의 주요 관절 동작인 피치(pitch) 동작만을 고려하였다. 좌우 대칭을 가정하고 총 6개 관절을 염색체로 구성하었다.

로봇의 초기 자세는 모든 관절각 값이 ' 0 '이며, 이는 염색 체에 포함되지 않는다. 반복적 실험을 통하여 동작의 마무리 시점은 약 $640 \mathrm{~ms}$ 로 고정시켰으며, 각 시점은 해당 관절의 염색체 크기로 균둥 분할한다.

\begin{tabular}{|c|c|c|c|}
\hline joint & $\mathrm{t} 1$ & $\mathrm{t} 2$ & $\mathrm{t} 3$ \\
\hline shoulder & 01 & $\ldots$ & \\
\hline elbow & & & \\
\hline back1 & - & & \\
\hline hip2 & & & \\
\hline knee & & & \\
\hline ankle1 & & $\cdots$ & 18 \\
\hline
\end{tabular}

그림 3. 염색체 표현

Fig. 3. Chromosome representation

그림 3 은 각 관절의 염색체 크기가 3 개씩 조합되어 총 18 개의 스트링으로 표현된 염색체를 보이고 있다.

\section{2 적합도 함수}

넘어짐 자세 생성을 위한 적합도 함수의 구성은 $\mathrm{ZMP}$ (Zero Moment Point)와 CoM(Center of Mass)의 거리 차 와 지면에 접촉되는 손, 팔꿈치, 무를, 둥, 엉덩이 압력 센서 값을 누적 시킨 경우와 ZMP가 아닌 $\mathrm{CoM}$ 의 원점으로부터 뼌화된 $\mathrm{CoM}$ 의 거리 차와 지면 접촉 압력센서 값을 지면과 닿는 순간부더 일정 스텝 동안 누적 시킨 경우로 구성하였다.

식 (1)과 (2)는 전면, 식 (3) 과 (4)는 후면 넘어짐 자세의 적합도 함수로 사용되어진 수식을 보이고 있다. 로봇의 진행 방향이 $\mathrm{Z}$ 축이고, 측면이 $\mathrm{X}$ 축이 된다.

식 (1)과 (3)의 적합도 함수는 $\mathrm{ZMP}$ 가 고정된 위치가 아니 므로 지면에서 $\mathrm{CoM}$ 과의 거리가 불규칙적으로 변화하며 압 력센서 값 또한 모든 구간을 누적 시키지만, 식 (2)와 (4)의 적합도 함수는 $\mathrm{CoM}$ 의 원점을 기준점으로 하여 거리를 계산 하고 압력센서가 켜진 순간부터 일정 구간 동안의 센서 값을 누적시켰다.

$1 / \sum_{i=1}^{m} \sqrt{\left(Z x_{i}-C x_{i}\right)^{2}+\left(Z z_{i}-C z_{i}\right)^{2}}$

$+\sum_{i=1}^{m}\left(1 /\right.$ Hen $_{i}+1 /$ Esen $_{i}+1 /$ Ksen $\left._{i}\right)$

$\sum_{i=1}^{m}\left\{\begin{array}{c}-\sqrt{\left(O c x_{i}-C x_{i}\right)^{2}+\left(O c z_{i}-C z_{i}\right)^{2}} \\ +\left(1 / \text { Hsen }_{i}+1 / \text { Esen }_{i}+1 / \text { Ksen }_{i}\right)\end{array}\right\}+k$

$1 / \sum_{i=1}^{m} \sqrt{\left(Z x_{i}-C x_{i}\right)^{2}+\left(Z z_{i}-C z_{i}\right)^{2}}$

$+\sum_{i=1}^{m}\left(1 / H_{\operatorname{sen}_{i}}+1 /\right.$ Esen $_{i}+1 /$ Bsen $_{i}+1 /$ hen $\left._{i}\right)$ 


$$
\sum_{i=1}^{m}\left\{\begin{array}{c}
-\sqrt{\left(O c x_{i}-C x_{i}\right)^{2}+\left(\overline{\left.O c z_{i}-C z_{i}\right)^{2}}\right.} \\
\left(1 / \text { Hsen }_{i}+1 / \text { Esen }_{i}+1 / \text { Bsen }_{i}+1 / \text { sen }_{i}\right)
\end{array}\right\}+k
$$

$\mathrm{Zx}: \mathrm{ZMP}$ 의 $\mathrm{X}$ 축 좌표

$\mathrm{Zz}: \mathrm{ZMP}$ 의 $Z$ 축 좌표

$\mathrm{Ocx}: \mathrm{CoM}$ 의 $\mathrm{X}$ 축 원점

$\mathrm{Ocz}: \mathrm{CoM}$ 의 $Z$ 축 원점

$\mathrm{Cx}: \mathrm{CoM} \mathrm{X}$ 축 좌표

$\mathrm{Cz}: \mathrm{CoM} Z$ 축 좌표

Hsen, Esen, Ksen, Bsen, hsen :

손, 팔꿈치, 무륲, 등, 엉덩이의 압력 센서값

(' 0 '일 경우, $\infty$ 로 가정)

$\mathrm{k}$ : 보정상수

\section{3 관절 움직임의 보간}

휴머노이드 로봇의 유연한 넘어짐 동작을 위하여 관절각 의 변화에 가감속 구간을 생성하여 더욱 부드러운 움직임으 로 동작하도록 3차식 보간법을 사용하였다[4].

식 (5)에서의 $q$ 와 $\dot{q}$ 은 각각 시간 $\mathrm{t}$ 에 따른 관절각과 각속 도 값을 나타낸다.

$$
\begin{aligned}
& q_{i+1}=a_{i} t_{e}^{3}+b_{i} t_{e}^{2}+c_{i} t_{e}+d_{i} \\
& q^{i+1}=3 a_{i} t_{e}^{2}+b_{i} t_{e}+c_{i} \\
& q_{i}=a_{i} t_{s}^{3}+b_{i} t_{s}^{2}+c_{i} t_{s}+d_{i} \\
& q^{\prime i}=3 a_{i} t_{s}^{2}+2 b_{i} t_{s}+c_{i} \\
& H_{i} x_{i} \equiv\left[\begin{array}{cccc}
t_{e}^{3} & t_{e}^{3} & t_{e} & 1 \\
3 t_{e}^{2} & 2 t_{e} & 1 & 0 \\
t_{s}^{3} & t_{s}^{2} & t_{s} & 1 \\
3 t_{s}^{2} & 2 t_{s} & 1 & 0
\end{array}\right]\left[\begin{array}{c}
a_{i} \\
b_{i} \\
c_{i} \\
d_{i}
\end{array}\right] \equiv\left[\begin{array}{c}
q_{i+1} \\
q_{i+1} \\
q_{i} \\
q_{i}
\end{array}\right] \equiv y_{i} \\
& x_{i}=\left(H_{i}\right)^{-1} y_{i}
\end{aligned}
$$

식 (5)를 식 (6)과 같이 행렬식으로 표현하여, 식 (7)로 3 차식의 계수 $\mathrm{X}_{\mathrm{i}}$ 를 구한 후, $q=\mathrm{F}(\mathrm{t})$ 를 이용하여 각 시점 $\mathrm{t}$ 의 관절각을 계산하여 보간한다.

\section{4. 실험 및 결과}

\section{1 시뮬레이션 환경}

시뮬레이션 환경은 Core 2 Duo $2.13 \mathrm{GHz} \mathrm{PC}$ 에서 Cyberbotics 사의 Webots를 사용하였다. Webots는 모바일 로봇에 대한 모델링, 프로그래밍, 그리고 시뮬례이션 기능을 제공하는 모바일 로봇 시뮬레이션 $\mathrm{s} / \mathrm{w}$ 이다. 각종 센서와 엑 튜에이터에 대한 라이브러리 제공, 정확한 physics 시뮬레이 션을 위한 ODE(Open Dynamics Engine) 라이브러러 제공, 그리고 실제 모바일 로봇에 컨트롤러를 전송 할 수 있는 기 능을 가지고 있다.

\section{$4.2 \mathrm{GA}$ 염색체 크기에 따른 영향력 분석}

$\mathrm{GA}$ 를 이용한 전방 넘어짐 자세의 생성에 있어서 관절 궤 적의 보간점 수를 나타내는 염색체의 크기를 결정해야 한 다. 엄색체는 각 시점에서 관절 공간에서의 관절각을 나타낸 다. 염색체 크기 결정을 위하여 각 관절 궤적의 보간점을 표
현하는 스트링을 1 부터 4 까지 변화시켜 실험 하였다

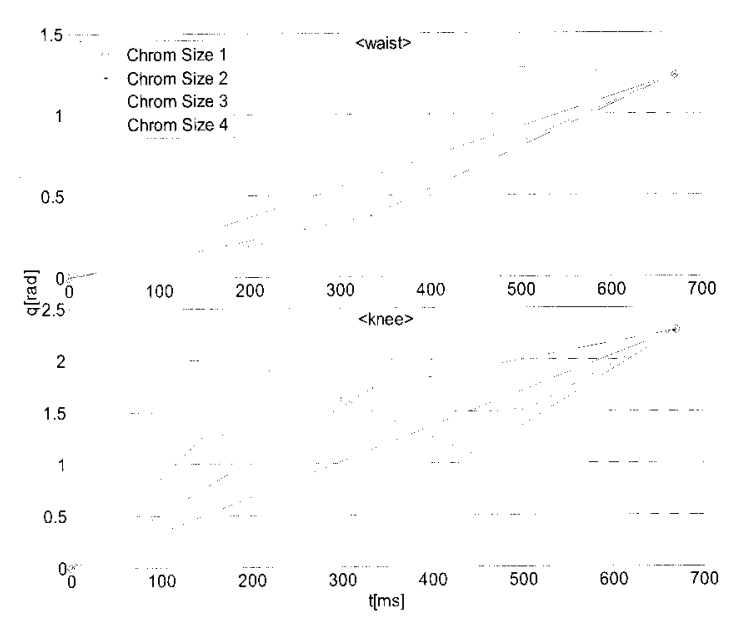

그림 4. 염색체 크기에 따른 관절각의 변화

Fig. 4. Joint angels by varied chromosome sizes

그림 4는 각 염색체 크기에 따른 허리와 무를 관절의 움직 임 변화를 보이고 있다. 2개 이하의 염색체 크기는 움직임을 생성하는대 제한적 오소가 되며, 4 개 이상은 비슷한 동작을 생성하는 반면 해의 탐색 영역이 넓어져 연산량을 증가시키 는 결과를 보여 각 관절의 염색체 크기가 3 일 경우, 가장 효 율적인 결과를 보였다.

\section{3 보간에 따른 움직임 변화}

3 차식을 사용하여 각 지점의 각도와 각속도 값(초기 ' 0 '으 로 설정)을 대입하여 염색체 사이의 중간 값을 보간하였다 (step1).

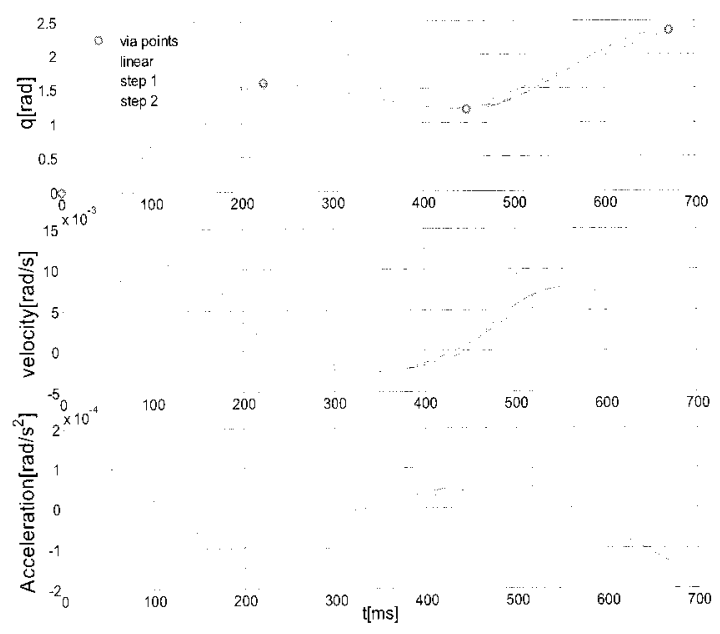

그림 5. 3차식 보간에 따른 각도, 각속도, 각가속도

Fig. 5. Joint angles, angular velocities, and angular accelerations

그 후, 각 염색체 값의 각속도 값을 ' 0 '으로 설정하였던 부 분의 제거를 위하여 2 번째와 3 번째 염색체 주변 일정 구간을 다시 보간하였다(step2).

시간에 따른 관절각 값의 선형 보간의 경우에는 각속도 
값이 계단함수 형태로 변화하여 각가속도 또한 ' 0 '으로 변화 가 없었으나 각속도의 변화를 유연한 곡선모양으로 변형시켜 관절각의 변화에 가감속 구간을 형성하었다. 그림 5 는 무릎 관절각 보간에 의한 각도, 각속도, 각가속도의 변화를 보이고 있다.

\section{4 실험 결과}

유전 알고리즘으로는 SGA(Simple Genetic Algorithm)를 사용하였으며 개체 수는 50 , 세대 수는 수행 시간을 고려하 여 50 세대로 설정 하였고 교배확률 $80 \%$, 돌연변이확률 $10 \%$ 를 사용하여 수행하였다.

로봇에 가해지는 외력은 $12[\mathrm{~N}]$ 의 힘을 로봇이 넘어지는 방향으로 가하였고 식 (1)과 식 (2)의 적합도 함수와 염색체 크기 변화에 따라 성능 비교를 위하여 5 회 반복 실험하였다. Core $2 \mathrm{Duo} 2.13 \mathrm{GHz} \mathrm{PC}$ 에서 시뮬레이션 평균 수행시간은 염색체 크기가 2 일 경우에는 약 3 시간 40 분, 염색체 크기가 3 일 경우에는 약 5 시간 10 분, 그리고 염색체 크기가 4 일 경 우에는 약 7 시간 20 분이 소요되었다.

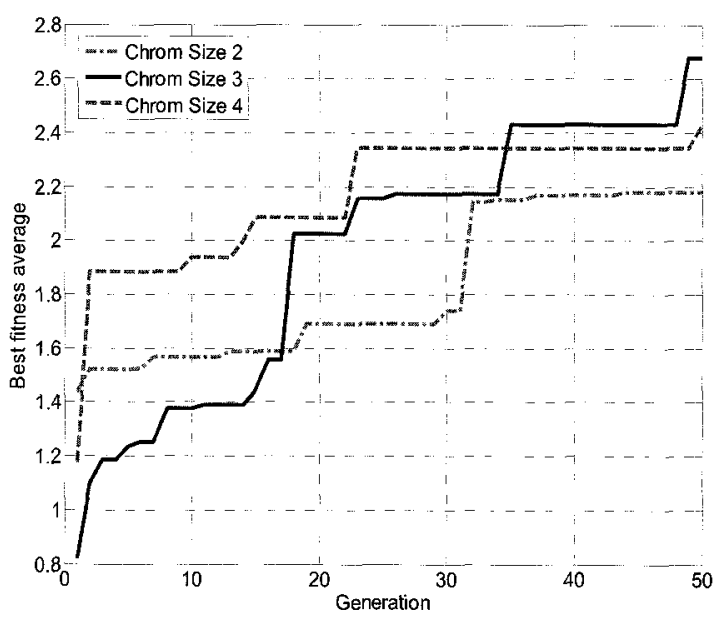

그림 6. 염색체 크기별 적합도 함수 (1) 의 성능

Fig. 6. Performances of fitness function (1) by varied chromosome sizes

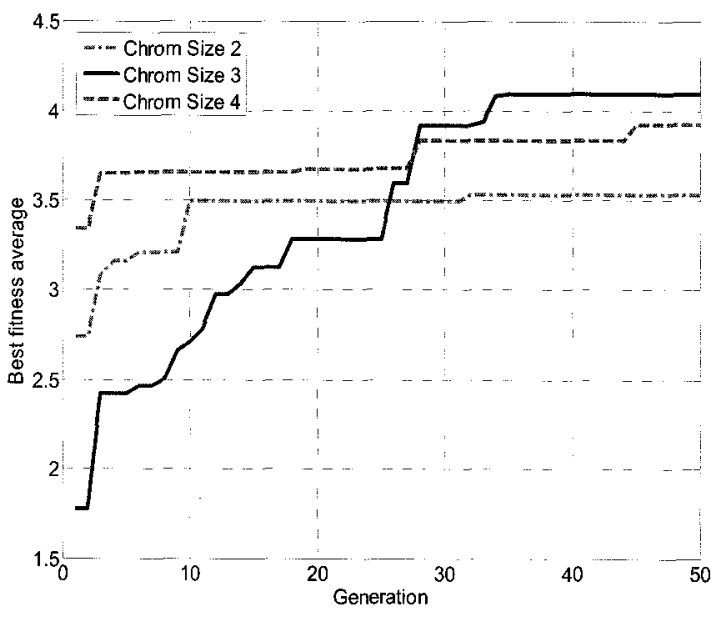

그림 7. 염색체 크기별 적합도 함수 (2) 의 성능

Fig. 7. Performances of fitness function (2) by varied chromosome sizes
그림 6과 7은 각각 식 (1)과 식 (2)의 적합도 함수에 따른 염색체 크기별 성능의 평균값을 나타낸다. 염색체 크기를 3 을 사용한 경우가 모두 가장 높은 성능을 보였다. 이하의 실 험에서는 염색체 크기를 3 으로 고정하여 사용하였다.

각각의 적합도 함수 정의에 대해 수행되어진 실험에서 최 고의 적합도를 가진 QRIO 로봇 넘어짐 자세의 시간별 움직 임과 관절 궤적 그래프가 아래에 나와 있으면 그림 8-11은 전방 넘어짐 결과, 그림 12-15는 후방 넘어짐 결과를 보여주 고 있다.

그림 8 은 전면으로 넘어지는 자세에 대해서 적합도 함수 (1)을 사용하여 얻은 결과로서 QRIO 로봇 넘어짐 자세의 시 간별 움직임을 보여주고 있다. 특징으로는 양손을 들어서 뒤 로 젖히는 자세를 취했다가 다시 앞으로 넘어지는 현상을 보 이고 있다. 그림 9 에는 그림 8 의 자세에 대한 6 개 관절각의 궤적이 나와 있다.

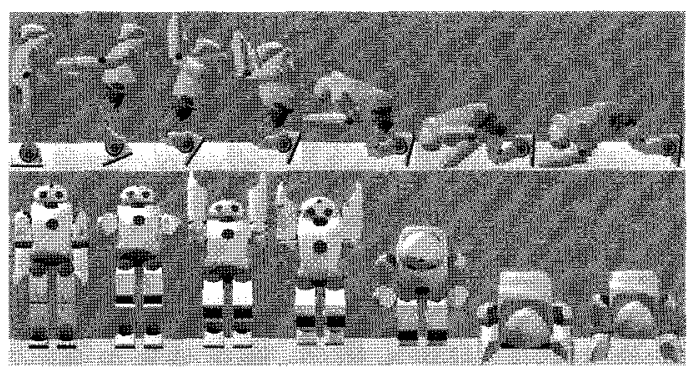

그림 8. 적합도 함수 (1) 에 의한 전방 넘어짐 동작

Fig. 8. Falling over motions by fitness function (1)

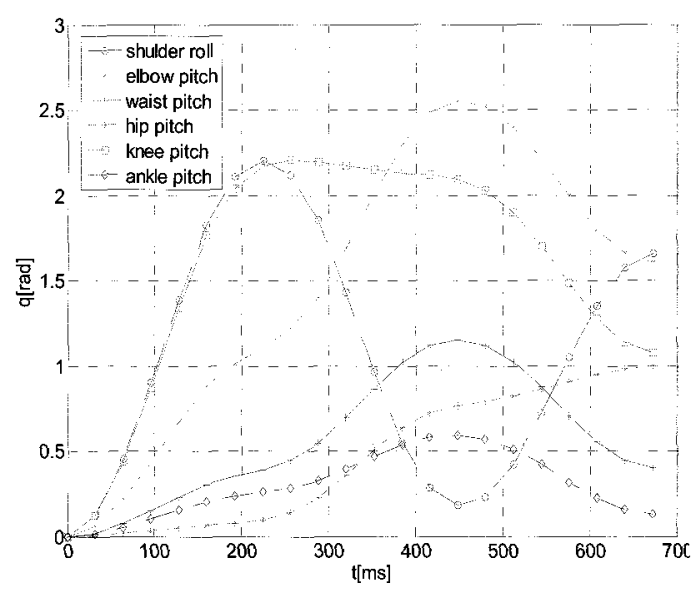

그림 9. 적합도 함수(식 1)에 의한 관절 궤적 Fig. 9. Joint trajectories by fitness function (1)

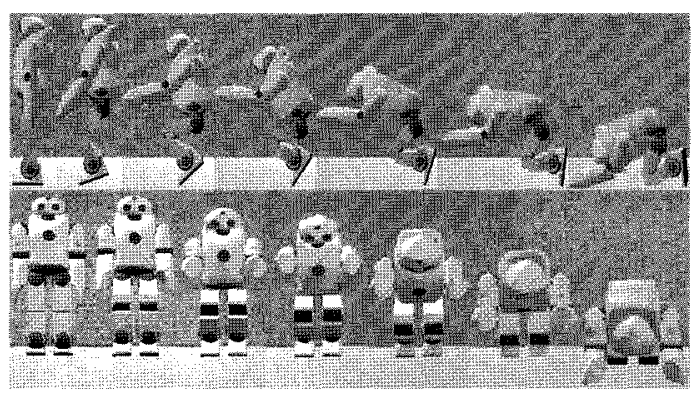

그림 10. 적합도 함수 (2) 에 의한 전방 넘어짐 동작

Fig. 10. Falling over motions by fitness function (2) 


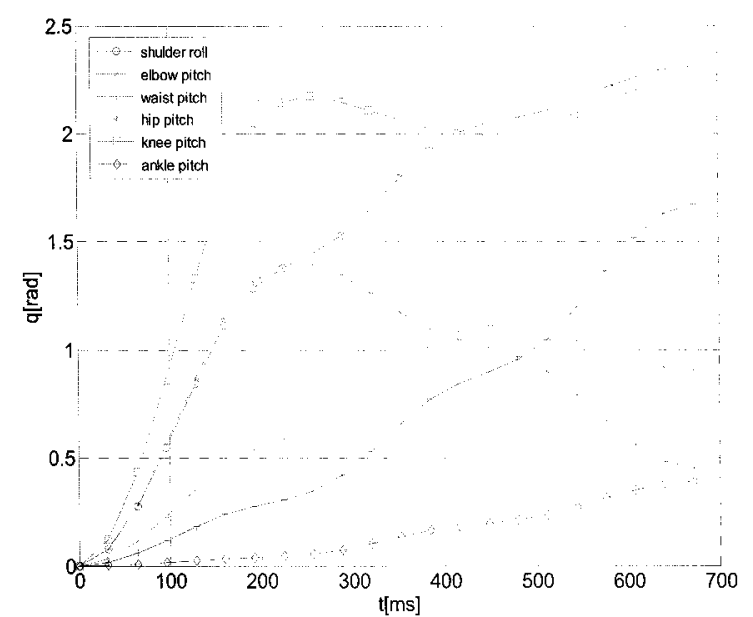

그림 11. 적합도 함수 (2) 에 의한 관절 궤적

Fig. 11. Joint trajectories by fitness function (2)

그림 12 와 13 에는 적합도 함수 (3)을 사용한 후방으로 넘 어지는 자세 생성에 대한 결과가 나와있다. 상체를 굽히고 다리를 펴는 자세를 취하는 모습을 보이고 있다. 그림 14 와 15 에는 적합도 함수 (4)을 사용한 걸과가 나와 있으며, 두 팔 로 지면을 짚으면서 엉덩방아를 찧는 모습을 보이며, 그림 12 와는 달리 완전히 뒤로 넘어지지 않고 주저앉고 있다.

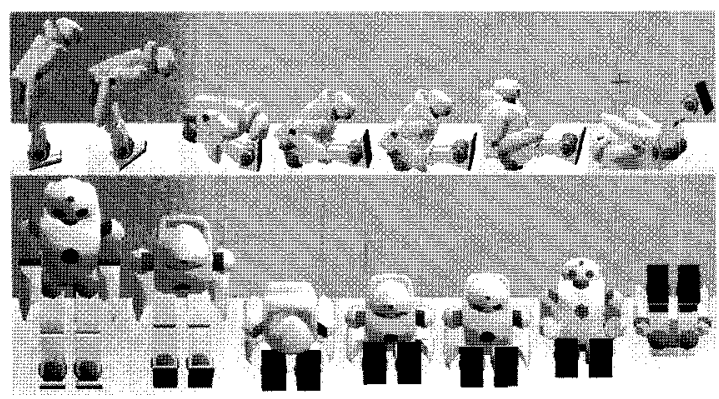

그림 12. 적합도 함수 (3) 에 의한 후방 넘어짐 동작

Fig. 12. Falling down motions by fitness function (3)

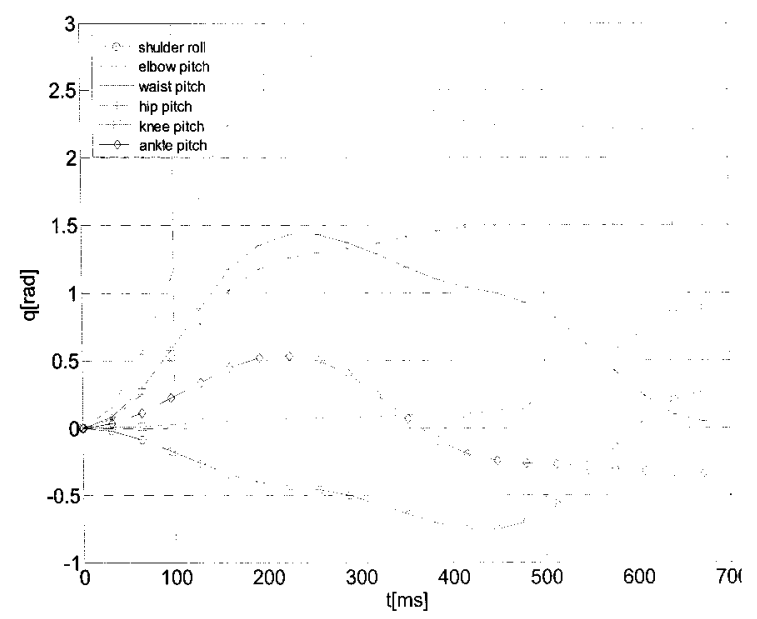

그림 13. 적합도 함수 (3) 에 의한 관절 궤적

Fig. 13. Joint trajectories by fitness function (3)

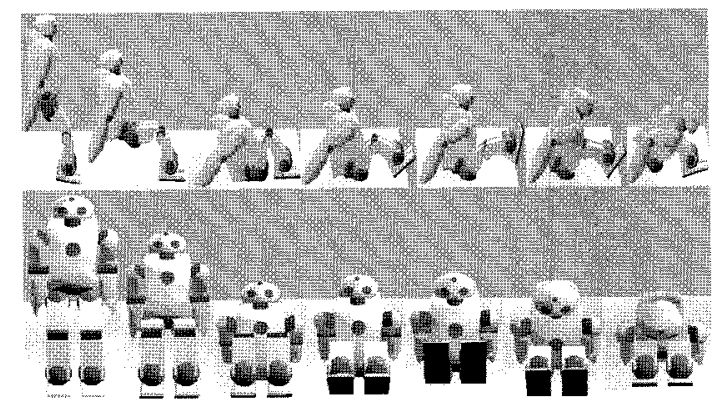

그림 14. 적합도 함수 (4) 에 의한 후방 넘어짐 동작

Fig. 14. Falling down motions by fitness function (4)

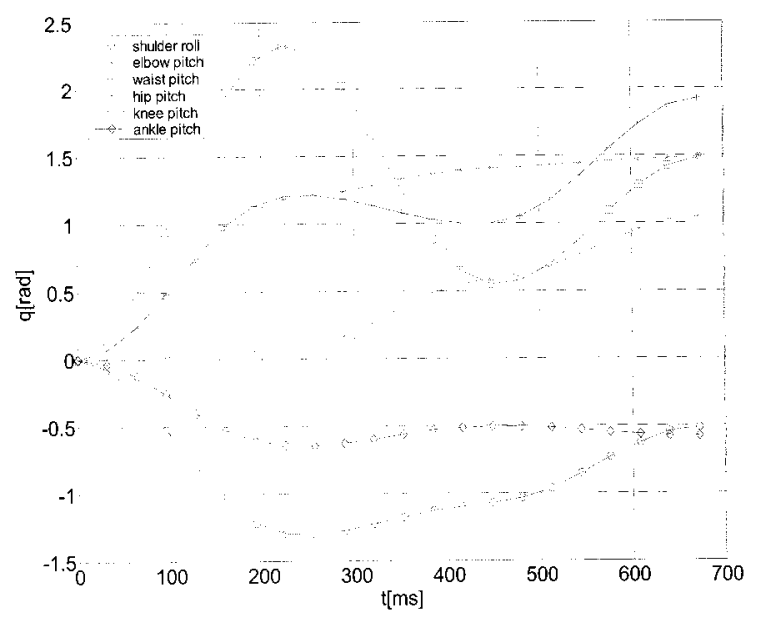

그림 15. 적합도 함수 (4) 에 의한 관절 궤적

Fig. 15. Joint trajectories by fitness function (4)

식 (1)과 (2)의 적합도 함수에 거리차 적합도 요소로 사용 되었던 $\mathrm{ZMP}$ 의 영향으로, 그림 8과 그림 12 는 넘어짐 자세 전반부에 $\mathrm{ZMP}$ 위치를 $\mathrm{CoM}$ 의 위치와 근접시키기 위한 움직 임을 보이고 있으며, 그림 10과 그림 14는 적합도 함수 (3) 과 (4)의 $\mathrm{CoM}$ 거리차를 줄이기 위하여 최종 동작까지 몸을 움츠리는 움직임을 보이고 있다.

\section{5. 결 론}

본 연구에서는 휴머노이드 로봇에 대해 GA를 이용하여 로봇이 넘어질 때 충격과 손상을 최소화하기 위한 자세를 자 동 생성하는 방법을 구현하였고, 로봇의 전방 넘어짐과 후방 넘어짐 자세에 대해서 다양한 적합도 함수를 정의하였다.

제안된 기법의 검증을 위하여 Sony QRIO 로봇에 대해서 $\mathrm{ODE}$ 기반의 물리적 특성을 갖춘 시뮬레이션이 가능한 Webots 를 이용하여 실험을 수행하였고, 충격랑을 만족할만한 수준으 로 최소화할수 있는 넘어짐 자세를 생성하였다.

향후 연구로, $\mathrm{GA}$ 알고리즘의 개선 및 측면 방향으로의 넘 어짐등 다양한 조건에 대한 연구가 필요하다. 


\section{참 고 문 헌}

[1] 최무성, 권오흥, 강민성, 박종현, “유전자 알고리즘을 이용한 이족 보행 로봇의 최적 설계 및 최적 보행 궤적 생성," 제어자동화시스템공학회 논문지, $\mathrm{Vol}$. 10, No. 9, 2004.

[2] 김용태, 노수희, 이희진, "이족보행로봇의 비평탄지형 보행 및 자세 안정화 알고리즘," 퍼지및지능시스템 학회 논문지, Vol. 15, No. 1, pp. 59-64, 2005.

[3] 박상수, 김병수, 오재준, 최윤호, "이족 로봇의 저전 력 보행 궤적 생성 및 구현,” 퍼지및지능시스템학회 논문지, Vol. 16, No. 4, pp. 443-448, 2006.

[4] Yariv Bachar, "Developing Controllers for Biped Humanoid Locomotion," MSc thesis, University of Edinburgh, 2004.

[5] 최국진, “유전알고리즘을 이용한 휴머노이드 로봇의 전신협조 동작의 최적화에 관한 연구," 공학석사학 위논문, 창원 대학교, 2004.

[6] Tatsuzo Ishida, Yoshihoro Kuroki, Taro Takahashi, "Analysis of Motions of a Small Biped Entertainment Robot," Proc, of IEEE/RSJ Int. Conf. Intelligent Robots and Systems, pp. 142-147, September 28-October 2, 2004, Sendai, japan.

[7] Kiyoshi Fujiwara, Fumio Kanehiro, Shuuji Kajita and Hirohisa Hirukawa, "Safe Knee Landing of a Human-size Humanoid Robot while Falling Forward," Proc. of IEEE/RSJ Int. Conf. Intelligent Robots and Systems, pp. 503-508, September 28-October 2, 2004, Sendai, japan.

[8] J. H. Holland, Genetic Algorithms in Search, Optimization and Machine Learning, AddisonWesley, Reading, MA, 1989.

[9] Cyberbotics, Webots Reference Manual release 5.1.9, 2006.

\section{저 자 소 개}

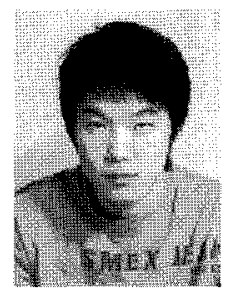

안광철(Kwang-chul An)

2007년 : 서경대학교 전자공학과 공학사 2007년 현재 : 서경대학교 전자공학과 석사과정

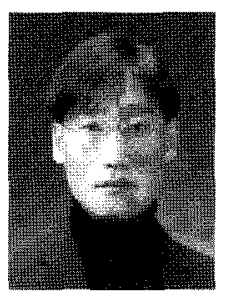

조영 완(Young-Wan Cho)

1991년 : 연세대학교 전자공학과 공학사 1993년 : 연세대학교 전자공학과 공학석사 1999년 : 연세대학교 전자공학과 공학박사 2000 2003년 : 삼성전자 디지털프린팅 사업부 책임연구원

2003 현재 : 서경대학교 컴퓨터공학과 조교수

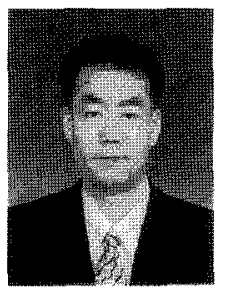

서기성(Kisung Seo)

1986년 : 연세대학교 전기공학과 공학사 1988년 : 연세대학교 전기공학과 공학석사 1993년 : 연세대학교 전기공학과 공학박사 1993 1998년 : 서경대학교 산업공학과 전임강사, 조.교수

1999 2002년 : Michigan State University, GARAGe (Genetic Algorithms Research and Applications Group), Research Associate

2002년 2003년 : Michigan State University, Electrical \& Computer Engineering, Visiting Assistant Professor

2003 2004년 : 서경대학교 전자공학과 조교수

2004 현재 : 서경대학교 전자공학과 부교수 